\title{
Tempting Fate: The Ethics of Dual-Use Research
}

\author{
Miller, Seumas \& Michael J. Selgelid (2008) Ethical and Philosophical \\ Consideration of the Dual-Use Dilemma in the Biological Sciences \\ (Dordrecht, The Netherlands: Springer), vii + 75 pp. ISBN 978-1-4020-8311-2
}

\author{
Adam Briggle
}

Received: 6 March 2009 / Accepted: 9 March 2009 / Published online: 20 March 2009

(C) The Author(s) 2009. This article is published with open access at Springerlink.com

There are two basic stories when it comes to the human pursuit of knowledge, one cautionary and one intrepid. Since Kant defined the Enlightenment with the dictum "Dare to know," the latter kind of story has been in ascendance. Take the tale of Faust as an iconic example. Traditionally a tragedy about the dire consequences of hubris, Faust became through Goethe's pen a saga of noble striving, in which the unfettered pursuit of knowledge brings great reward. The presumption in contemporary liberal democracies is that knowledge is a fundamental good and the freedom to pursue it is a basic human right.

But now consider a non-fiction story. In 1951, a doctoral student in microbiology named Johan Hultin dug through six feet of tundra and permafrost in Alaska. He then dug into the well-preserved bodies of four victims of the 1918 Spanish Flu pandemic. Hoping to recover live flu virus, he transported tissue samples to his lab in Iowa and exposed ferrets to them. The animals did not get sick and Hultin abandoned the project. But in 1995, scientists at the U.S. Armed Forces Institute of Pathology set about the task of resurrecting the flu virus from their collection of dried and fixed tissue from victims of the pandemic. Jeffry Taubenberger, the head of the division of molecular pathology, remarked "I really

A. Briggle $(\bowtie)$

University of Twente,

Enschede, The Netherlands

e-mail: a.r.briggle@gw.utwente.nl wanted to see if there was some way we could make use of this vast, wonderful collection" [1]. With Hultin's assistance and advanced genetic sequencing techniques, the attempt succeeded this time. In 2005, the complete genetic sequence of the 1918 influenza A (H1N1) virus was published in Science.

Note: They had just resurrected and published the blueprint for the greatest killer in human history. And that is not all. Scientists have published an article describing how to render the mousepox virus more virulent and immune to vaccination. They have synthesized the polio virus from scratch in order to warn society that terrorists could do the same. And they have built and tested bacteria-laden weapons for "threat assessment" purposes. This kind of research makes that thing Pandora opened look like a box of toys. One begins to wonder if this is what Kant had in mind.

The decision to publish the Spanish Flu genome was approved by a U.S. governmental advisory board, which concluded that the scientific benefit of the research far outweighed its potential risk of misuse. This knowledge could help scientists identify and combat the next pandemic. Of course, it could also be used to cause the next pandemic. Welcome to the dual-use dilemma, which Seumas Miller and Michael Selgelid argue arises from the fact that "one and the same piece of scientific research sometimes has the potential to be used for harm as well as for good" (p. 1). In this report, originally produced for the Australian government and previously published in Science and Engineering Ethics, Miller and Selgelid 
provide a concise, clear-headed, and helpful introduction to the policy and ethical implications of the dualuse dilemma in the biological sciences. It should be read by policymakers and scientists. Many others, including students and scholars studying the interactions of science, technology, and society, would benefit from this pithy report.

What the authors make clear is that the dilemma is fundamentally about trade-offs. Though knowledge and freedom of inquiry are fundamental moral values, they are not absolute values. They exist within a broader ecology of goods, including security and human health. Sometimes these synergize or serve one another, but at other times they clash, setting the stage for a tragedy: "research undertaken to promote human health might instead by used to destroy human health" (p. 3). When values collide, decisions must be made. With their keen analytic abilities, Miller and Selgelid have created an excellent guide for such decisions, both in terms of moral reasoning and public policy options.

Though they freely admit that the devil is often in the details, meticulous ethical analysis is simply beyond the scope of their report. Instead, they conceptually frame and parse the relevant moral questions, establishing a framework to guide analyses in particular cases. Their primary emphasis is on the need to maintain a "commonsense position" that strikes a "reasonable balance" between competing values (p. 44). They helpfully show how this can be cast in both utilitarian (e.g., balancing potential benefits against potential costs) and deontological (e.g., balancing rights to free inquiry against rights to security or health) terms. Virtue ethics is also laced throughout the report. After all, there is no dual-use dilemma without the vicious character of certain nefarious individuals eager to twist the good intentions of others into malevolence. And a great deal rides on the moral and intellectual virtues of scientists who are pursuing potentially dangerous knowledge and must discern their responsibilities.

Throughout, Miller and Selgelid rightly emphasize the uncertainty that characterizes any kind of moral reasoning in the dual-use dilemma. Uncertainty is magnified, because the actors involved are responsive to the problem and to the actions of others. Managing uncertainty requires building in capacities for creative solutions. Indeed, the authors emphasize creativity or "designing-in ethics," not only for this reason, but also because it can negate the need to make a tradeoff, allowing "us to have our cake and eat it" (p. 4).

Miller and Selgelid succeed in crafting a guide to thinking that is concise and focused on the essentials. They are able to do so by adopting the U.S. National Research Council's tactic of mapping the dual-use dilemma atop a set of salient "experiments of concern." This gives them concrete material for structuring their moral considerations and public policy recommendations. There are other ways to structure an analysis of the dual-use dilemma. For example, one could attempt a taxonomy of types of artifacts (e.g., bench-top DNA synthesizer) that cut across different experiments. This would have the added benefit of casting the dual-use dilemma in a wider lens. After all, nearly all knowledge and artifacts, despite good intentions, can produce foreseeable bad effects. Pens can become stabbing instruments, and commercial airplanes can become missiles. Miller and Selgelid are clearly aware of this and would most likely concede the importance of reflecting on dual-use more broadly.

But their purpose is more narrowly defined, and their choice of framework allows them, in the final chapter, to identify and analyze a set of policy options regarding the imposition of limits on dual-use research and the dissemination of potentially dangerous knowledge. This is the most original and useful portion of the report. The resulting matrix stretches horizontally across a continuum of five options ranging from the least to the most intrusive or restrictive. For example, option one grants full autonomy to the scientific community, whereas option five gives the government "ultimate and overriding decision-making authority in relation to dual-use research and dual-use publication" (p. 61). The vertical axis of the matrix is populated by six categories of decision. These include questions of who should make the decisions about research and dissemination or censorship of findings, whether there should be mandatory regulations, whether there should be licensing of dual-use technologies/techniques, and whether there should be mandatory education, training, and personnel security restrictions.

Miller and Selgelid make the case that an independent panel (independent of research institutions and government) may be the best option for the location of decision-making authority. Of course, ensuring independence will be difficult as the panel would require funding. This independent body "would be comprised 
of scientists, security experts... and ethicists" (p. 59). Noticeably absent is any "lay" member of society. The argument, presumably, is that some mechanic, baker, housewife, or lawyer would not have any relevant expertise to offer. Perhaps not, but, then again, this might be precisely why they are needed. Experts have a way of thinking narrowly - that is why we call them specialists. They also have a tendency to become jaded through training and blinded by methodology. The hope, frankly, is that where experts would bury their noses in cost-benefit equations, a non-expert would be attuned to the absurdity of resurrecting viruses or engineering more virulent pathogens. Absent this corrective, a panel of myopic experts seems more likely to approve research justified by such dubious constructs as "threat assessment." It is just this kind of cold, abstract jargon that simultaneously animates expert discourse and deadens our powers of moral imagination.

Open Access This article is distributed under the terms of the Creative Commons Attribution Noncommercial License which permits any noncommercial use, distribution, and reproduction in any medium, provided the original author(s) and source are credited.

\section{Reference}

1. Brown D (2008) Resurrecting 1918 Flu Virus Took Many Turns. Washington Post, Oct. 10, p A08 